\title{
Alternative splicing in heart surgery: Lost in translation?
}

\author{
Tyson A. Fricke, MBBS, BMedSci, ${ }^{\mathrm{a}, \mathrm{b}, \mathrm{c}}$ Michael Z. L. Zhu, MBBS, BMedSci, ${ }^{\mathrm{a}}$ and
} Igor E. Konstantinov, MD, PhD, FRACS ${ }^{\mathrm{a}, \mathrm{b}, \mathrm{c}, \mathrm{d}}$

\footnotetext{
From the a'Department of Cardiac Surgery, The Royal Children's Hospital, Parkville, Australia; 'Department of Paediatrics, The University of Melbourne, Melbourne, Australia; ${ }^{\mathrm{c}}$ Murdoch Children's Research Institute, Melbourne, Australia; and ${ }^{\mathrm{d}}$ Melbourne Children's Centre for Cardiovascular Genomics and Regenerative Medicine, Melbourne, Australia.

Disclosures: Authors have nothing to disclose with regard to commercial support

Received for publication Oct 18, 2018; accepted for publication Oct 18, 2018; available ahead of print Dec 8, 2018 .

Address for reprints: Igor E. Konstantinov, MD, PhD, FRACS, Royal Children's Hospital, Flemington Rd, Parkville 3052, Australia (E-mail: igor.konstantinov@ rch.org.au).

J Thorac Cardiovasc Surg 2019;157:997-8

$0022-5223 / \$ 36.00$

Crown Copyright (C) 2018 Published by Elsevier Inc. on behalf of The American Association for Thoracic Surgery https://doi.org/10.1016/j.jtcvs.2018.10.097
}

Relentless pressure of survival has shaped molecular evolution in the most unusual ways. Among the stunning examples of such molecular evolution is the ability of some animals to withstand the rigors of winter. With no escape from the cold, some animals fall into hibernation. These animals have developed an amazing ability to survive winter by slowing their metabolism and saving vital energy. An astute mind cannot help but wonder if such a remarkable adaptation could be utilized for the benefit of patients undergoing heart surgery.

It appears that the decrease in body temperature that occurs in a hibernating animal or in a patient undergoing heart surgery with hypothermia induces rapid production of cold-inducible RNA-binding protein (CIRP). ${ }^{1}$ CIRP is an evolutionarily conserved RNA-binding protein that is ubiquitously expressed in both animals and humans. ${ }^{2}$ It has a number of roles and is upregulated in hypothermia, hypoxia, and inflammation. ${ }^{3}$ The expression of CIRP peaks during temperatures of $28^{\circ} \mathrm{C}$ to $34^{\circ} \mathrm{C}$ and may have a neuroprotective effect in cold temperatures. ${ }^{2}$ It appears that temperature-regulated alternative splicing may result in translation of different proteins in normothermia and hypothermia. Through alternative splicing, a rapid increase in CIRP levels is produced during hypothermia compared with normothermia where a dominant-negative protein overrides the functional form of CIRP. ${ }^{1}$ Alternative splicing is nature's way by which 2 or more distinct proteins can be translated from a single gene (Figure 1). Can protection be lost in translation or gained? Alternative splicing may become a valuable, innate switch readily available for clinical use in surgery in the era of personalized genomic medicine. However, such clinical translation has to be used with caution until the end effects of the CIRP are fully elucidated. This is particularly important because other studies have highlighted CIRP's potent proinflammatory effects. In a murine model of liver

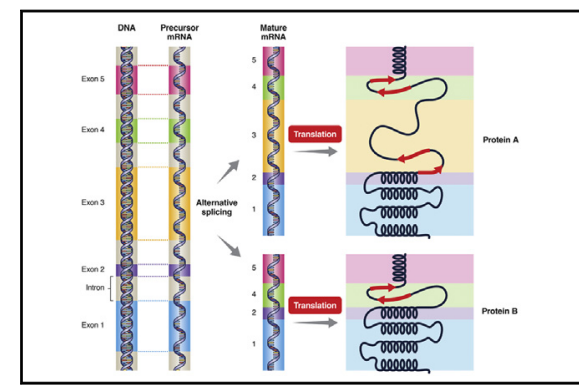

A phenomenon of alternative splicing occurs when 1 or more exons are not translated.

Central Message

Cold-inducible RNA-binding protein may be protective against cardiopulmonary bypassinduced brain injury.

See Article page 986

ischemia-reperfusion, it was demonstrated that anti-CIRP treatment reduced the severity of ischemia-reperfusion injury. ${ }^{4}$ Similarly, anti-CIRP treatment reduced the severity of renal ischemia-reperfusion injury in yet another murine model. ${ }^{5}$ In humans, increased levels of CIRP were found in patients admitted to an intensive care unit with hemorrhagic shock ${ }^{6}$ and have been found to be a prognostic indicator of poor outcome in patients with sepsis. Further research has demonstrated that in sepsis, CIRP caused the release of proinflammatory cytokines from macrophages ${ }^{6}$ and activated splenic T cells.

Liu and colleagues ${ }^{9}$ offer an insightful and thoughtprovoking article on the effect of CIRP on cardiopulmonary bypass (CPB)-induced brain injury. The authors divided 15 rats into 3 groups (ie, sham group, $\mathrm{CPB}$ group, and $\mathrm{CPB}$ group without CIRP expression). Rats were placed on CPB (or in the case of the sham group, cannulated without institution of $\mathrm{CPB}$ ), cooled to $32^{\circ} \mathrm{C}$, and arrested for $30 \mathrm{mi}$ nutes before reperfusion. They found that in rats genetically engineered to not express CIRP there was more histologic evidence of disruption of the blood-brain barrier as well as a more severe injury to hippocampal neurons. This led to the conclusion that CIRP was protective against CPBinduced brain injury by reducing the breakdown of the blood-brain barrier. This is an exciting study because deeper insight into manipulation of alternative splicing may provide clinicians with a subtle, yet powerful, means of natural protection during the metabolic stress of surgery. Will this study translate into clinical practice? Time will tell. 


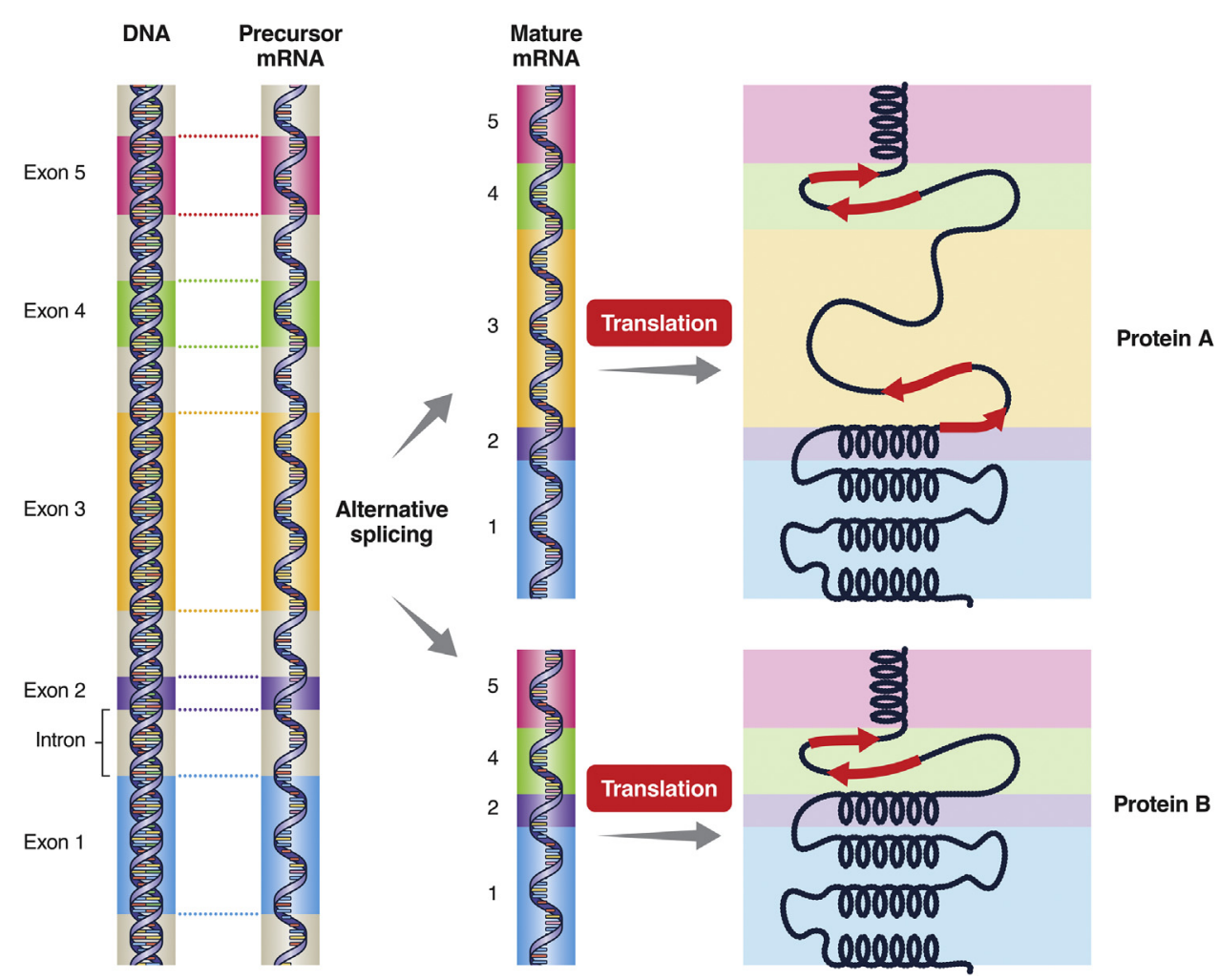

FIGURE 1. A phenomenon of alternative splicing occurs when 1 or more exons are not translated. This results in production of different proteins from the same gene. mRNA, Messenger RNA.

\section{References}

1. Sano Y, Shiina T, Naitou K, Nakamori H, Shimizu Y. Hibernation-specific alternative splicing of the mRNA encoding cold-inducible RNA-binding protein in the hearts of hamsters. Biochem Biophys Res Commun. 2015;462: $322-5$.

2. Zhu X, Bührer C, Wellmann S. Cold-inducible proteins CIRP and RBM3, a unique couple with activities far beyond the cold. Cell Mol Life Sci. 2016; 73:3839-59.

3. Zhong P, Huang H. Recent progress in the research of cold-inducible RNA-binding protein. Future Sci OA. 2017;3:FSO246.

4. Godwin A, Yang W-L, Sharma A, Khader A, Wang Z, Zhang F, et al. Blocking cold-inducible RNA-binding protein (CIRP) protects liver from ischemia/reperfusion injury. Shock. 2015;43:24-30.
5. Cen C, Yang W-L, Yen H-T, Nicastro JM, Coppa GF, Wang P. A novel cold shock protein induces renal injury after ischemia-reperfusion. J Am Coll Surg. 2015;221(Suppl):S40.

6. Qiang X, Yang W-L, Wu R, Zhou M, Jacob A, Dong W, et al. Cold-inducible RNA-binding protein (CIRP) triggers inflammatory responses in hemorrhagic shock and sepsis. Nat Med. 2013;19:1489-95.

7. Zhou Y, Dong H, Zhong Y, Huang J, Lv J, Li J. The cold-inducible RNA-binding protein (CIRP) level in peripheral blood predicts sepsis outcome. PLoS One. 2015; 10:e0137721.

8. Bolognese AC, Sharma A, Yang W-L, Nicastro J, Coppa GF, Wang P. Cold-inducible RNA-binding protein activates splenic T cells during sepsis in a TLR4dependent manner. Cell Mol Immunol. 2016;15:38-47.

9. Liu M, Li Y, Liu Y, Yan S, Liu G, Zhang Q, et al. Cold-inducible RNA-binding protein as a novel target to alleviate blood-brain barrier damage induced by cardiopulmonary bypass. J Thorac Cardiovasc Surg. 2019;157:986-96. 